\title{
Risk factors for graft failure in allogeneic hematopoietic stem cell transplantation: a single-center study
}

Igor Novitzky-Basso ${ }^{1}$, Eshrak Al-Shaibani ${ }^{1}$, Mats Remberger ${ }^{2}$, Carol Chen ${ }^{1}$, Wilson Lam ${ }^{1}$, Arjun D. Law ${ }^{1}$, Ivan Pasic ${ }^{1}$, Fotios V. Michelis ${ }^{1}$, Auro Viswabandya ${ }^{1}$, Dennis D. Kim ${ }^{1}$, Jeffrey H. Lipton ${ }^{1}$, Armin Gerbitz ${ }^{1}$, Jonas Mattsson ${ }^{1}$, Rajat Kumar ${ }^{1}$, Zeyad Al-Shaibani ${ }^{1}$

${ }^{1}$ Hans Messner Allogeneic Transplant Program, Princess Margaret Cancer Centre, University Health Network, University of Toronto, Toronto, Canada

${ }^{2}$ Department of Medical Sciences, Uppsala University and KFUE, Uppsala University Hospital, Uppsala, Sweden

Igor Novitzky-Basso MD PhD, Hans Messner Allogeneic Transplant Program, Princess Margaret Cancer Centre, University Health Network, University of Toronto, 610 University Avenue, Toronto, ON, M5G 2M9, Canada-
Phone: +1 6479278700

Fax: +1 4169464407

E-mail: igor.novitzkybasso@uhn.ca

Citation: Novitzky-Basso I, Al-Shaibani E, Remberger M et al. Risk factors for graft failure in allogeneic hematopoietic stem cell transplantation: a single-center study. Cell Ther Transplant 2020; 9(4): 37-47.

\section{Summary}

\section{Objectives}

Graft failure (GF) following allogeneic hematopoietic stem cell transplantation (allo-HCT) has a dismal prognosis. This study assessed incidence, risk factors (RF) and outcome of GF in a single-center population.

\section{Patients and methods}

Between 2015-2018, 557 patients underwent allo-HCT. Primary GF (PGF) was defined as failure to achieve absolute neutrophil count (ANC) of $>0.5 \times 10^{9} / \mathrm{L}$ by 28 days after allo-HCT. Secondary GF (SGF) was characterized by loss of donor cells after initial engraftment with recurrence of $\mathrm{ANC}<0.5 \times 10^{9} / \mathrm{L}$ without relapse or other causes of cytopenia. Endpoints of the study were cumulative incidence of GF and overall survival (OS). Risk factors for GF were assessed in multivariate analysis.

\section{Results}

Nine patients had PGF, and 34 had SGF. The cumulative incidence of GF overall (primary and secondary) is $1.6 \%$ (CI95\%; 0.8-3.0\%) at day 100 and 6.5\% (CI95\%; $4.5-8.8 \%)$ at day 800 respectively. Multivariate analysis showed diagnosis (myelodysplastic syndrome [MDS], myelofibrosis [MF], lymphoma or non-malignant diseases) and donor type (HLA-mismatched-unrelated or haploidentical) were significantly associated with GF. For the absence of any of the risk factors $(n=279)$, the incidence of GF was 3.6\%. For the presence of one risk factor $(n=229)$, the incidence of GF was $9.9 \%$, while for 2 concurrent risk factors $(n=49)$, the incidence of GF was $24.5 \%(\mathrm{p}=0.002)$.

Median OS of patients following PGF was 41 days, SGF - 144 days. The D100 OS in PGF was $22 \%$, SGF $64 \%$; 2 -year overall survival for SGF was $28 \%$.

\section{Conclusions}

This study showed increased risk of GF following mismatched-unrelated or haploidentical donor allo-HCT or for non-leukemia diagnosis, for which we suggest close monitoring for early diagnostic and therapeutic interventions, in order to improve clinical outcomes.

\section{Keywords}

Allogeneic hematopoietic stem cell transplantation, graft failure, incidence, risk factors. 


\section{Introduction}

Allogeneic hematopoietic stem cell transplantation (alloHCT) is a potentially curative therapy for hematological diseases. Sustained engraftment of the donor stem cells is essential for transplant success and overall favourable outcomes. Graft failure (GF) is an uncommon (incidence 5-6\%) complication post-allo-HCT and is associated with a poor prognosis, especially in allo-HCT for malignant disorders [1]. There are differences in the definition of primary and secondary graft failure [1-10]. Numerous risk factors have been previously associated with GF such as myelofibrosis (MF), aplastic anemia (AA), bone marrow as a graft source or donor HLA mismatch, while other factors such as ABO mismatch, graft-versus-host disease prophylaxis or infections, particularly viral reactivation, remain a matter of debate [11]. The incidence of GF may increase to $20-25 \%$ with the use of alternative modalities of HCT, including non-myeloablative conditioning, intensive T-cell depletion of the graft, human leukocyte antigen (HLA) disparity between donor and recipient or cord blood as the progenitor source $[1,11]$. The use of filgrastim-mobilized peripheral blood (PB) stem cells instead of bone marrow (BM) decreases the risk of GF, especially in unrelated allo-HCT [8]. Many factors have been proposed to be involved in the etiology of GF, including defects in the BM microenvironment, immune-mediated rejection, drug toxicity or viral infections $[12,13]$.

The management of GF includes the administration of growth factor, additional hematopoietic progenitor boost or a second allo-HCT with conditioning therapy $[11,13]$. Data available on patient outcomes after the development of GF are limited and heterogeneous. Strategies for reversing GF depend on the options available in each situation, and there is no clear recommendation for the best approach to this complication. Some reports have suggested that a second transplant could benefit patients who develop GF [14]. However, transplant-related mortality compromises the overall survival (OS) of these patients. In the present study, we assessed the incidence and the risk factors for GF in a single-center population and the impact on the patients' outcome.

\section{Patients and methods}

Between January 1, 2015, and December 31, 2018, 557 patients underwent allo-HCT at the Princess Margaret Cancer Center. Data was collected retrospectively and updated in June 2019. Cases were included regardless of the underlying diagnosis, disease status prior to transplant, preparative regimen, or stem cell source. Acute (aGvHD) and chronic GvHD (cGvHD) were diagnosed and graded using the aGvHD consensus conference criteria and the NIH consensus criteria for cGvHD, respectively $[15,16]$. Conditioning therapy was considered as nonmyeloablative when patients received busulfan $<9 \mathrm{mg} / \mathrm{kg}$, and total body irradiation $\leq 500 \mathrm{cGy}$ as a single fraction or $\leq 800 \mathrm{cGy}$ if fractionated. All patients received granulocyte colony-stimulating factor from day +6 following transplant until neutrophil engraftment.

Primary graft failure was defined as the failure to achieve an absolute neutrophil count (ANC) of $0.5 \times 10^{9} / \mathrm{L}$ by 28 days af- ter BM or PB [17]. Secondary graft failure was defined as sustained fall in ANC $<0.5 \times 10^{\circ} / \mathrm{L}$ after initial engraftment, and one of the following: (a) donor chimerism of less than $5 \%$, or (b) intervention such as use of DLI or second transplant for falling blood counts, or (c) patient death due to cytopenia, with falling donor chimerism, but level of donor chimerism $>5 \%$ but $<95 \%[1,17]$. Decrease in peripheral blood counts due to relapse of disease was excluded as a cause of GF. Outcomes examined included overall survival (OS), the cumulative incidence of GF and non-relapse mortality (NRM) as well as the cause of death.

Patients were managed clinically according to Princess Margaret Cancer Center guidelines. BM aspirates were monitored for disease status and donor chimerism was assessed in sex-mismatched donor-recipient pairs by metaphase karyotype analyses; restriction fragment length DNA polymorphisms were compared in sex-matched pairs; whole blood chimerism was assay for the duration of this study.

This study was approved by the institutional research ethics board of our center, and consent had been obtained from all the patients for transplant procedures and sharing data following local policies.

Overall survival (OS) was calculated using the Kaplan-Meier method and compared with the log-rank test. Survival time was calculated from the day of first transplantation until death or last follow-up. Incidences of graft failure (GF) were obtained using an estimator of cumulative incidence curves. Patients were censored at the time of death or last follow-up. Competing events for GF were death or relapse without GF. For SGF, PGF was also considered as a competing event.

Uni- and multivariate predictive analyses for GF were performed with the proportional sub-distribution hazard regression model of Fine and Gray [18]. Factors with a p-value $<0.10$ in the univariate analysis were included in the backwards elimination multivariate analysis.

Analyses were performed using the EZR freely available software and Statistica 13 (TIBCO, Palo Alto, CA, USA) software [19].

\section{Results}

Baseline characteristics are summarized in Table 1. Pretransplant therapies where indicated for hematological malignancies consisted of current North American induction protocols: for ALL, Dana Farber Cancer Institute regimen for ALL (1 patient received blinatumomab); for AML either daunorubicin and cytarabine (' $3+7$ ') or FLAG-Ida; for MDS/ MPN supportive care, azacytidine, hydroxyurea or ' $3+7$ '; ruxolitinib for $\mathrm{MF}$, ibrutinib for CLL, and standard salvage regimens (Bendamustine/rituximab or 'ICE') for non-Hodgkin lymphoma.

GF was seen in $43(7.7 \%)$ patients. Of these 43 patients, 9 (21\%) had PGF, and 34 (79\%) had SGF. The median time to PGF was 31 days (25-75), and to SGF it was 97 days (28-764) (Figure 1a). The cumulative incidence of GF overall (primary and secondary) is $1.6 \%$ (CI95\%; $0.8-3.0 \%)$ at day 100 and $6.5 \%$ (CI95\%; $4.5-8.8 \%)$ at day 800 respectively. 
CLINICAL STUDIES

Table 1. Patients' characteristics and main factors contributing to GF

\begin{tabular}{|c|c|c|c|c|}
\hline Parameter & No GF & Primary GF & Secondary GF & $\begin{array}{l}\text { p-value } \\
\text { (PGF vs SGF) }\end{array}$ \\
\hline Number & 514 & 9 & 34 & 0.22 \\
\hline Median Age & $58(18-74)$ & $58(29-72)$ & $56(18-69)$ & 0.70 \\
\hline Sex (M/F) & $303 / 211$ & $6 / 2$ & $18 / 16$ & \\
\hline $\begin{array}{l}\text { Diagnosis } \\
\text { Acute leukemia } \\
\text { AML } \\
\text { ALL } \\
\text { MDS/MF } \\
\text { MF } \\
\text { CML/CLL } \\
\text { Lymphoma } \\
\text { Other malignant } \\
\text { Non-malignant }\end{array}$ & $\begin{array}{l}311 \\
273 \\
38 \\
92 \\
40 \\
35 \\
25 \\
4 \\
7\end{array}$ & $\begin{array}{l}1 \\
1 \\
0 \\
4 \\
3 \\
0 \\
0 \\
0 \\
1\end{array}$ & $\begin{array}{l}13 \\
10 \\
3 \\
6 \\
4 \\
3 \\
6 \\
0 \\
2\end{array}$ & $\begin{array}{l}<0.001 \\
0.0015 \\
0.66 \\
0.57 \\
0.08 \\
0.78 \\
0.03 \\
0.80 \\
0.08\end{array}$ \\
\hline $\begin{array}{l}\text { Donor } \\
\text { 10/10 MRD } \\
\text { 10/10 MUD } \\
\text { 9/10 MUD } \\
\text { Haploidentical }\end{array}$ & $\begin{array}{l}158 \\
229 \\
64 \\
63\end{array}$ & $\begin{array}{l}1 \\
1 \\
2 \\
5\end{array}$ & $\begin{array}{l}6 \\
14 \\
8 \\
6\end{array}$ & 0.05 \\
\hline $\begin{array}{l}\text { Graft source } \\
\text { BM } \\
\text { PB }\end{array}$ & $\begin{array}{l}11 \\
503\end{array}$ & $\begin{array}{l}1 \\
8\end{array}$ & $\begin{array}{l}3 \\
31\end{array}$ & 0.02 \\
\hline $\begin{array}{l}\text { Fresh } \\
\text { Frozen }\end{array}$ & $\begin{array}{l}338 \\
176\end{array}$ & $\begin{array}{l}6 \\
3\end{array}$ & $\begin{array}{l}23 \\
11\end{array}$ & 0.97 \\
\hline Donor age & $35(8-74)$ & $42(26-71)$ & $35(18-70)$ & 0.80 \\
\hline $\begin{array}{l}\text { Conditioning } \\
\text { MAC } \\
\text { RIC }\end{array}$ & $\begin{array}{l}91 \\
423\end{array}$ & $\begin{array}{l}0 \\
9\end{array}$ & $\begin{array}{l}4 \\
30\end{array}$ & 0.26 \\
\hline $\begin{array}{l}\text { T-cell depletion ATG/PTCy/CSA } \\
\text { Campath/CSA } \\
\text { ATG-CSA-MTX } \\
\text { PTCy-CSA } \\
\text { CSA-MTX } \\
\text { CSA-MMF } \\
\text { N/A OR OTHER }\end{array}$ & $\begin{array}{l}343 \\
48 \\
37 \\
2 \\
50 \\
28 \\
6\end{array}$ & $\begin{array}{l}7 \\
0 \\
1 \\
0 \\
1 \\
0\end{array}$ & $\begin{array}{l}24 \\
5 \\
3 \\
2 \\
0 \\
0\end{array}$ & \\
\hline $\begin{array}{l}\text { ABO mismatch } \\
\text { No mismatch } \\
\text { Minor } \\
\text { Major } \\
\text { unknown }\end{array}$ & $\begin{array}{l}278 \\
95 \\
102 \\
3\end{array}$ & $\begin{array}{l}7 \\
0 \\
2 \\
0\end{array}$ & $\begin{array}{l}12 \\
10 \\
12 \\
0\end{array}$ & \\
\hline CMV serological mismatch & 207 & 3 & 19 & 0.18 \\
\hline Day to GF & N/A & $31(25-75)$ & 97 (28-764) & \\
\hline
\end{tabular}

Abbreviations: MDS, myelodysplasia; MF, myelofibrosis; CML, chronic myeloid leukemia; CLL, chronic lymphocytic leukemia; MUD, matched unrelated donor; MRD, matched related donor; MAC, myeloablative conditioning; RIC, reduced-intensity conditioning; PTCY, post-transplant cyclophosphamide; ATG, anti-thymocyte globulin; MMF, myecophenolate; CSA, cyclosporine; MTX, methotrexate; CMV, cytomegalovirus; BM, bone marrow; PBSC, peripheral blood stem cells; BSI, bloodstream infections; HCT-CI, hematopoietic stem cell transplant co-morbidity index; KPS, Karnofsky performance score 
The cumulative incidence of relapse (CIR) for the entire cohort $(\mathrm{n}=557)$ was $7.9 \%(\mathrm{CI} 95 \% ; 5.9-10.3)$ at 100 days and $24.3 \%(\mathrm{CI} 95 \% ; 20.6-28.1)$ at 2 years. In particular, the CIR for patients transplanted for AML $(n=284)$ was $7.7 \%$ (CI95\%; 5.0-11.2) at 100 days and 21.4\% (CI95\%; 16.7-26.6) at 2 years, whereas it was $14.6 \%(\mathrm{CI} 95 \% ; 5.8-27.2)$ at 100 days and $45.0 \%(\mathrm{CI} 95 \% ; 27.9-60.6 \%)$ at 2 years in patients transplanted for ALL $(n=41)$. For MF $(n=47)$, CIR was $2.1 \%$ (CI95\%; 0.2-9.9) at 100 days and $10.2 \%$ (CI95\%; 2.9-22.8) at 2 years, CIR for MDS/MPN ( $\mathrm{n}=102)$ was $11.8 \%$ (CI95\%; 6.4-18.9) at 100 days and 30.4\% CI95\%; (21.5-39.8) 2 years. Finally, CIR of patients transplanted for Lymphoma $(\mathrm{n}=31)$ was $6.5 \%(\mathrm{CI} 95 \% ; 1.1-18.9)$ at 100 days, and 36.6\% (CI95\%; 19.6-53.8) at 2 years.
Median survival following PGF was 41 days, while in SGF it was 144 days (Figure 1b). The one hundred days OS in PGF was $22 \%$, whereas it was $64 \%$ for SGF. One-year and twoyear OS for SGF were $33 \%$ and $28 \%$, respectively, Figure $1 \mathrm{~b}$. Survival of GF patients was calculated from the date of GF.

Percentage donor chimerism (Figure 1c), was as follows: for primary graft failure, at day 30 post-transplant, $n=9$, median $19.9 \%(0.8-75.7 \%)$, at day 60 post-transplant, $n=5$, median $0 \%(0-27 \%)$, at day 90 post-transplant, $\mathrm{n}=3$, median $1 \%(0$ $1 \%)$. For secondary graft failure, at day 30 post-transplant, $\mathrm{n}=33$, median $96.85 \%$ (70.4-100\%) (missing data for one patient), at day 60 post-transplant, $n=32$, median $87.65 \%$ (0-99.3\%), at day 90 post-transplant, $\mathrm{n}=24$, median $74.15 \%$ (3.2-98.2\%).
A

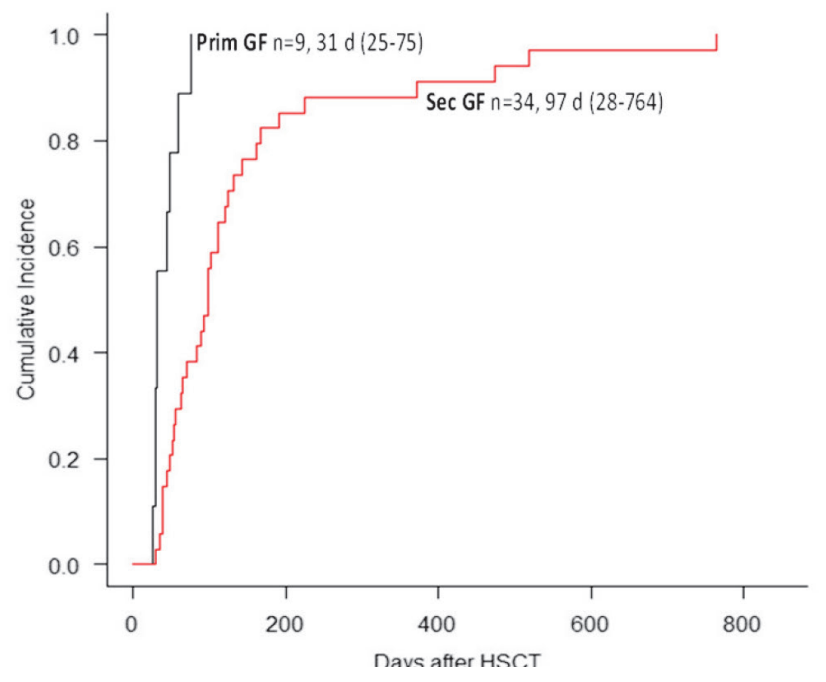

C

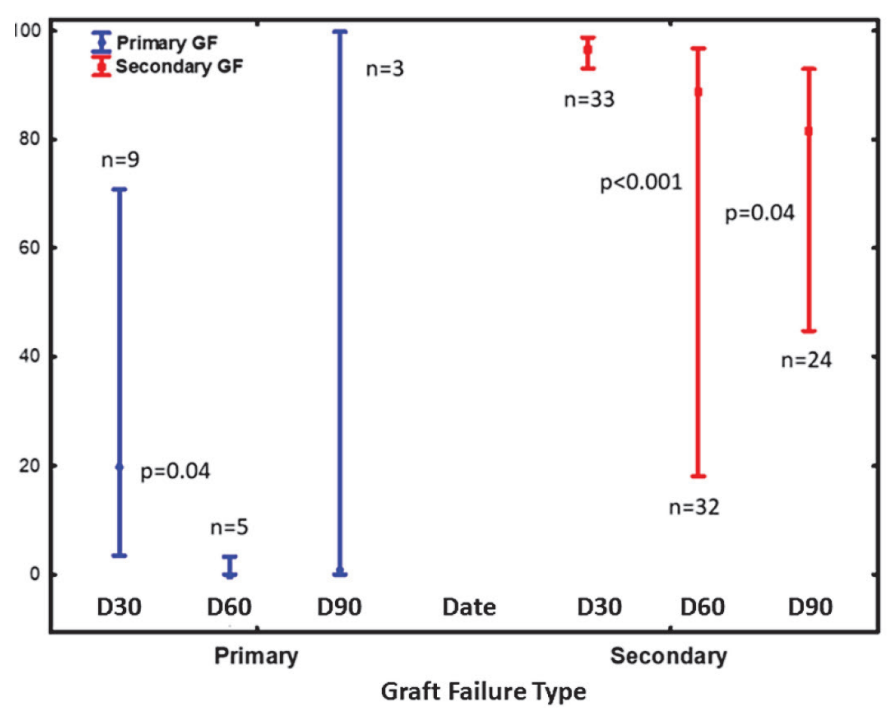

B

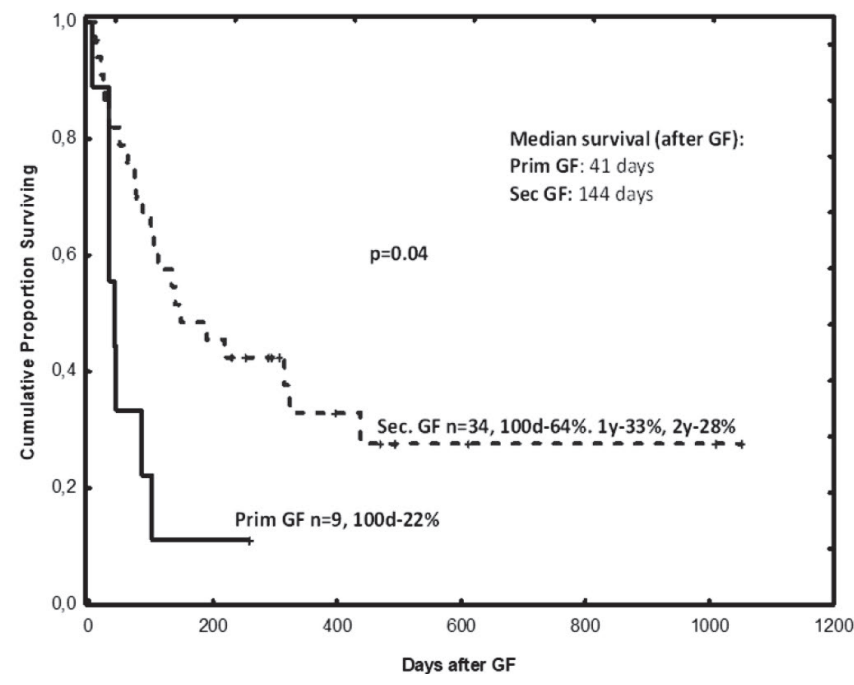

D

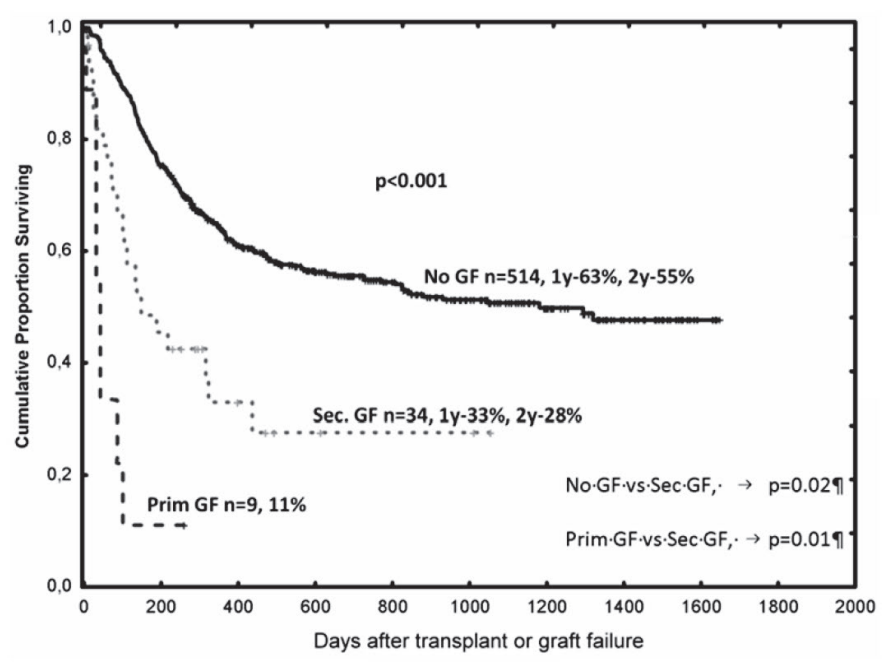

Figure 1. A, cumulative incidence to primary and secondary graft failure (GF). Numbers represent median number of days to graft failure diagnosis with range. B, median survival from primary and secondary graft failure. C, percentage donor chimerism in patients with primary and secondary graft failure. Bars represent the inter-quartile range, and round circles, the median. The percentage donor chimerism at day 30 (D30), day 60 (D60) and day 90 (D90) post-transplant are represented. D, overall survival from allogeneic stem cell transplant for the whole cohort, and patients with GF. Survival of GF patients was calculated from date of GF. 
Table 2. Results of univariate analysis

\begin{tabular}{|c|c|c|c|}
\hline Factor & HR & $95 \% \mathrm{Cl}$ & p-value \\
\hline $\begin{array}{l}\text { Diagnoses: } \\
\text { Myelodysplasia } \\
\text { Myelofibrosis } \\
\text { Chronic Leukemia } \\
\text { Lymphoma } \\
\text { Other Malignant } \\
\text { Non-Malignant } \\
\text { Acute Leukemia }\end{array}$ & $\begin{array}{l}2.37 \\
3.62 \\
1.77 \\
4.44 \\
0.00 \\
8.33 \\
\text { Ref }\end{array}$ & $\begin{array}{l}1.05-5.33 \\
1.46-8.98 \\
0.51-6.17 \\
1.71-11.6 \\
0.0-0.0 \\
2.39-29.0\end{array}$ & $\begin{array}{l}0.037 \\
0.005 \\
0.37 \\
0.002 \\
0.99 \\
<0.001\end{array}$ \\
\hline Age (per 10y) & 0.92 & $0.75-1.14$ & 0.46 \\
\hline $\begin{array}{l}\text { Type of donor: } \\
\text { Haploidentical } \\
\text { Matched unrelated donor } \\
\text { Mismatched unrelated donor } \\
\text { Matched related donor }\end{array}$ & $\begin{array}{l}4.02 \\
1.62 \\
3.61 \\
\text { Ref }\end{array}$ & $\begin{array}{l}1.56-10.4 \\
0.67-3.90 \\
1.31-9.96\end{array}$ & $\begin{array}{l}0.004 \\
0.29 \\
0.013\end{array}$ \\
\hline Female patient vs male & 0.89 & $0.49-1.63$ & 0.72 \\
\hline $\begin{array}{l}\text { Disease Stage: } \\
\text { Not CR } \\
\text { CR 2-3 } \\
\text { CR1 } \\
\end{array}$ & $\begin{array}{l}2.26 \\
0.28 \\
\text { Ref }\end{array}$ & $\begin{array}{l}1.21-4.24 \\
0.04-2.10\end{array}$ & $\begin{array}{l}0.01 \\
0.21\end{array}$ \\
\hline Donor age (per 10y) & 1.01 & $0.82-1.24$ & 0.92 \\
\hline $\begin{array}{l}\text { Stem cell source: } \\
\text { BM vs PBSC }\end{array}$ & 4.13 & $1.47-11.6$ & 0.007 \\
\hline CD34+ cell-dose & 0.99 & $0.91-1.06$ & 0.70 \\
\hline Fresh vs frozen graft & 1.09 & $0.58-2.07$ & 0.79 \\
\hline MAC vs RIC & 0.47 & $0.17-1.33$ & 0.16 \\
\hline PTCy vs no PTCy & 1.62 & $0.80-3.28$ & 0.18 \\
\hline ATG vs no ATG & 2.75 & $0.85-8.90$ & 0.09 \\
\hline CMV serological mismatch vs match & 1.50 & $0.83-2.73$ & 0.18 \\
\hline BSI before d20 vs no BSI & 1.26 & $0.63-2.49$ & 0.52 \\
\hline $\begin{array}{l}\text { Disease Type: } \\
\text { Secondary } \\
\text { Therapy Related } \\
\text { Primary Disease }\end{array}$ & $\begin{array}{l}0.37 \\
0.69 \\
\text { Ref }\end{array}$ & $\begin{array}{l}0.09-1.56 \\
0.21-2.24\end{array}$ & $\begin{array}{l}0.18 \\
0.54\end{array}$ \\
\hline $\begin{array}{l}\text { Disease risk index:22 } \\
\text { Low } \\
\text { High-Very High } \\
\text { IM }\end{array}$ & $\begin{array}{l}1.27 \\
0.81 \\
\text { Ref }\end{array}$ & $\begin{array}{l}0.44-3.65 \\
0.33-1.97\end{array}$ & $\begin{array}{l}0.66 \\
0.64\end{array}$ \\
\hline $\begin{array}{l}\text { Time from diagnosis to transplant, } \\
\text { per } 100 \text { days }\end{array}$ & 1.01 & $0.99-1.03$ & 0.50 \\
\hline KPS at SCT $<90$ vs $90-100$ & 1.30 & $0.63-2.66$ & 0.48 \\
\hline $\begin{array}{l}\mathrm{HCT}-\mathrm{Cl} \text { at } \mathrm{SCT}: 2^{20} \\
>2 \\
1-2 \\
0 \\
\end{array}$ & $\begin{array}{l}0.70 \\
0.48 \\
\text { Ref }\end{array}$ & $\begin{array}{l}0.34-1.43 \\
0.22-1.03\end{array}$ & $\begin{array}{l}0.33 \\
0.06\end{array}$ \\
\hline $\begin{array}{l}\text { Blood group match: } \\
\text { Major mismatch } \\
\text { Minor mismatch } \\
\text { Bidirectional } \\
\text { Match }\end{array}$ & $\begin{array}{l}1.78 \\
1.23 \\
0.72 \\
\text { Ref }\end{array}$ & $\begin{array}{l}0.88-3.58 \\
0.54-2.78 \\
0.17-3.06\end{array}$ & $\begin{array}{l}0.11 \\
0.63 \\
0.65\end{array}$ \\
\hline
\end{tabular}

Abbreviations: MAC, myeloablative conditioning; RIC, reduced intensity conditioning; PTCY, post-transplant cyclophosphamide; ATG, anti-thymocyteglobulin; BM, bone marrow; PBSC, peripheral blood stem cells; BSI, bloodstream infection; HCT-CI, hematopoietic stem cell transplant co-morbidity index; KPS, Karnofsky performance score; SCT, stem cell transplant; CR, complete remission 
DLI was administered to nine patients with SGF. Five of these experienced grade I-II acute GvHD, and two, grade III-IV acute GvHD. Two subsequently experienced moderately severe GvHD. Of these nine patients, one experienced relapse and died, another demised with post-transplant lymphoproliferative disorder, two with GvHD, and ultimately 5 were alive at last follow-up.

Second allo-HCT was performed in 5 patients (56\%) with PGF and 15 patients (44\%) with SGF (see Table 4). Another 8 patients with SGF received donor lymphocyte infusions (DLI). The primary complication following second allo-HCT was infection. Median time from GF diagnosis to second
allo-HCT was 35 days (20-172), whilst median time from GF diagnosis to DLI was 90 days (7-288). Six out of 15 patients who received a second transplant for SGF developed Grade 3/4 acute GvHD and 4 out of these patients developed moderately severe chronic GvHD.

Median survival (Figure 1d) post second transplant was 109 days (9-1014); survival was calculated from second HCT. Median survival post DLI was 293 days (22-868).

Overall, all the patients with PGF died because of GF or complications related to it. In SGF 22 of 43 patients (51\%) died, the most common causes of death were infections (30\%),

Table 3. Results of multivariate analysis for factors associated with GF

\begin{tabular}{|l|l|l|l|l|}
\hline \multirow{2}{*}{} & \multicolumn{3}{|c|}{ Parameter estimate GF } \\
\cline { 2 - 5 } & P value & Hazard ratio & 95\% Hazard ratio lower CL & 95\% Hazard ratio upper CL \\
\hline Myelodysplasia & 0.049 & 2.21 & 1.00 & 4.85 \\
\hline Myelofibrosis & 0.005 & 3.63 & 1.47 & 8.98 \\
\hline Lymphoma & 0.002 & 4.65 & 1.77 & 12.2 \\
\hline Non-malignant & $<0.001$ & 9.80 & 2.67 & 36.0 \\
\hline Acute Leukemia & Ref. & 1.00 & & \\
\hline Haplo-donor & 0.002 & 3.25 & 1.55 & 6.83 \\
\hline Mismatched unrelated donor & 0.045 & 2.33 & 1.02 & 5.32 \\
\hline Matched related donor & Ref. & 1.0 & & \\
\hline
\end{tabular}

Table 4. Characteristics of patients who underwent a second transplant for GF

\begin{tabular}{|c|c|c|}
\hline & Primary GF & Secondary GF \\
\hline Number & 4 & 15 \\
\hline Sex (M/F) & $3 / 1$ & $8 / 7$ \\
\hline Median Age & 62 (43-66) & 48 (18-68) \\
\hline $\begin{array}{l}\text { Diagnosis } \\
\text { AML } \\
\text { ALL } \\
\text { MF } \\
\text { MDS/MPN } \\
\text { CLL } \\
\text { Non-malignant }\end{array}$ & $\begin{array}{l}0 \\
0 \\
2 \\
2 \\
0 \\
0\end{array}$ & $\begin{array}{l}5 \\
4 \\
2 \\
1 \\
1 \\
2\end{array}$ \\
\hline $\begin{array}{l}\text { Same donor } \\
\text { Different donor } \\
\text { 10/10 MUD } \\
\text { 9/10 MUD } \\
\text { Haplo } \\
\end{array}$ & $\begin{array}{l}2 \\
2 \\
0 \\
1 \\
1 \\
\end{array}$ & $\begin{array}{l}9 \\
6 \\
2 \\
3 \\
1 \\
\end{array}$ \\
\hline \multicolumn{3}{|l|}{ Complications } \\
\hline Relapse & No & No \\
\hline $\begin{array}{l}\text { GvHD } \\
\text { a.GvHD } \\
\text { c.GvHD }\end{array}$ & $\begin{array}{l}\text { Grade } 3, n=1 \\
n=0\end{array}$ & $\begin{array}{l}\text { Grade } 1, n=1 \\
\text { Grade } 2, n=3 \\
\text { Grade } 3 / 4, n=6 \\
\text { Moderately severe, } n=4\end{array}$ \\
\hline $\begin{array}{l}\text { Survival } \\
\text { Alive } \\
\text { Died } \\
\text { Cause of death }\end{array}$ & $\begin{array}{l}0 \\
4 \\
\text { Infection, } n=3, G v H D, n=1\end{array}$ & $\begin{array}{l}6 \\
9 \\
\text { Infection, } n=5, G v H D, n=4\end{array}$ \\
\hline
\end{tabular}

Abbreviations: GF, graft failure; AML, acute myeloid leukemia; ALL, acute lymphoblastic leukemia; MF, myelofibrosis; MDS, myelodysplasia; $M P N$, myeloproliferative neoplasm; MUD, matched unrelated donor; GvHD, graft versus host disease 

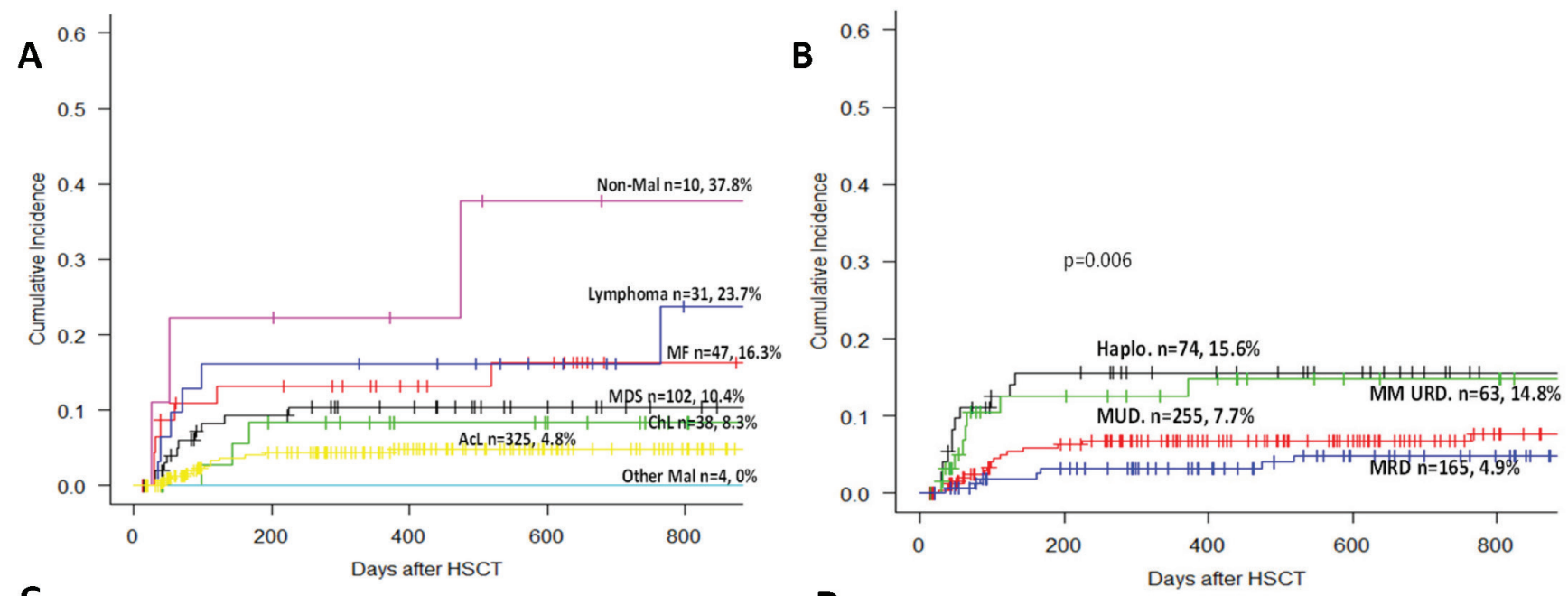

C
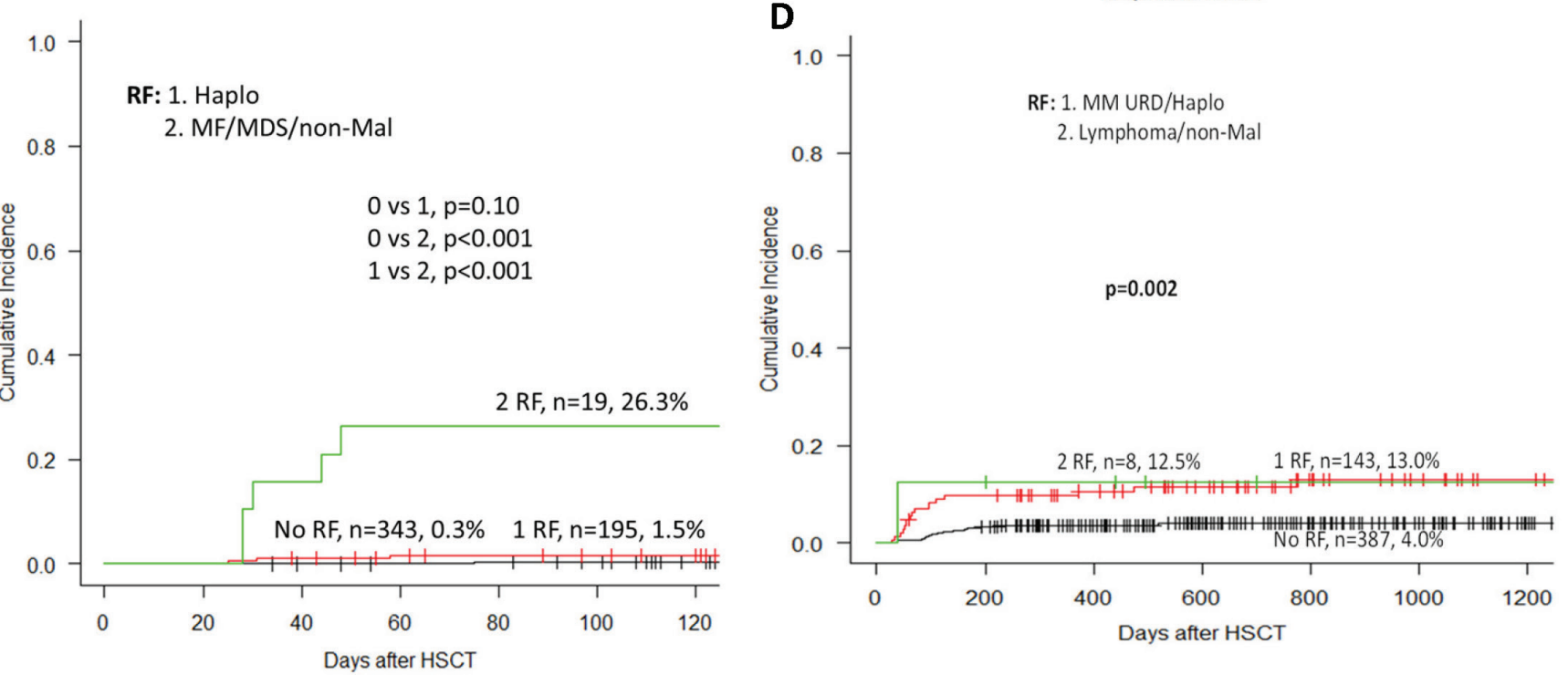

E

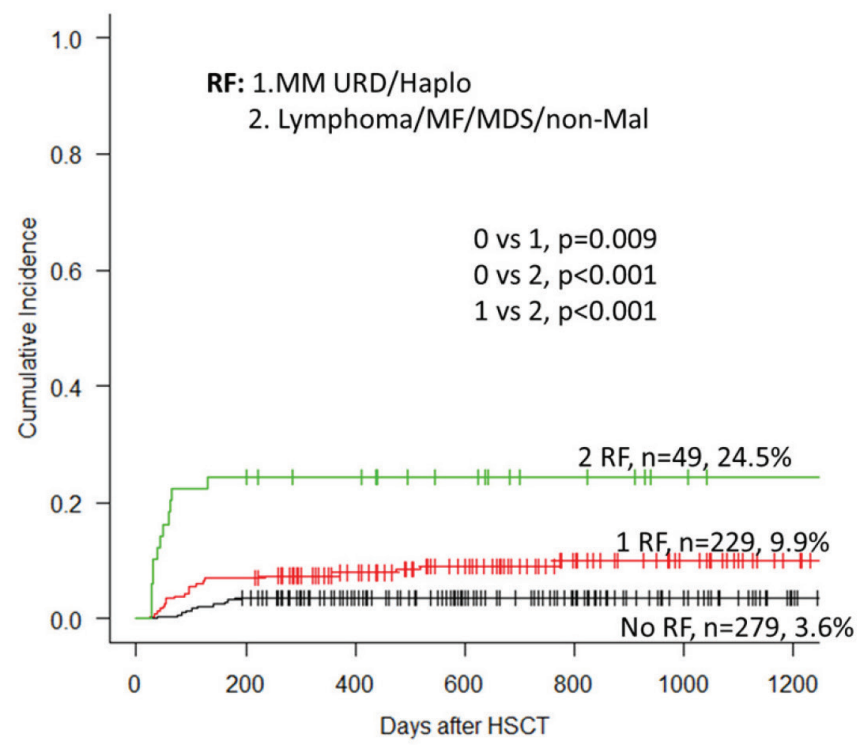

Figure 2. A, cumulative incidence of GF according to transplant indication/disease. B, cumulative incidence of GF

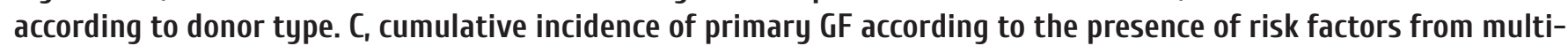
variable analysis. D, cumulative incidence of secondary GF according to the presence of risk factors from multivariable analysis. $\mathrm{E}$, cumulative incidence of overall GF from multivariable analysis according to the presence of no risk factors $(3.6 \%), 1$ risk factor $(9.9 \%)$ and 2 risk factors $(24.5 \%)$.

Abbreviations: Haplo, haploidentical; MUD, matched unrelated donor; MMURD, mismatched unrelated donor; MRD, matched related donor; Other Mal, other malignancies; RF, risk factor 
GvHD (18\%) and one patient died related to veno-occlusive disease. The median neutrophil count for the SGF patients that died in GF was $0 \times 10^{9} / \mathrm{L}\left(0-0.5 \times 10^{9} / \mathrm{L}\right)$ and median platelet count was $6 \times 10^{9} / \mathrm{L}\left(3-41 \times 10^{9} / \mathrm{L}\right)$.

Factors associated with graft failure on univariate analysis are shown in Table 2. Diagnoses associated with GF were MDS $(\mathrm{p}=0.04), \mathrm{MF}(\mathrm{p}=0.005)$, lymphoma $(\mathrm{p}=0.002)$ and non-malignant conditions (aplastic anemia, adrenoleukodystrophy, mitochondrial neurogastrointestinal encephalopathy syndrome) $(\mathrm{p}<0.001)$. Other significant factors were incomplete remissions prior to allo-HCT $(\mathrm{p}=0.01)$, mismatched unrelated donors $(\mathrm{p}=0.002)$ or haploidentical donors $(\mathrm{p}=0.004)$, use of BM as graft source ( $\mathrm{p}=0.008)$. CMV mismatch, CD34 stem cell dose, and freezing of the stem cell product were not significant factors.

Multivariate analysis was undertaken with the following variables: diagnosis, age, donor type, sex, disease stage at allo-HCT, donor age, stem cell source, CD34 dose, stem cells frozen or fresh, myeloablative or reduced-intensity conditioning, use of post-transplant cyclophosphamide, use of anti-thymocyte globulin as GvHD prophylaxis, presence of CMV serological mismatch, presence of bloodstream infection before $\mathrm{D}+20$ post-allo-HCT, primary disease, disease risk index, Karnofsky performance score (KPS) at allo-HCT, HCT-CI (hematopoietic cell transplant co-morbidity in$\operatorname{dex}^{20}$ ) score, presence of donor and recipient of blood group mismatch, and time from diagnosis to transplant.

Multivariate analysis of all GF demonstrated that transplant indication (MDS, MF, lymphoma or non-malignant diseases) and donor type (HLA-mismatched unrelated or haploidentical) were the significant factors associated with increased GF (Table 3). For PGF significant factors were: non-malignant disease (HR 114.3 95\% confidence interval [CI] [4.53-2881], $\mathrm{p}<0.004$ ), MF (HR 27.6 [2.84-268], $\mathrm{p}=0.004$ ), MDS (HR 18.2 [1.99-166], $\mathrm{p}=0.01)$ and graft from haploidentical donor (HR 12.5 [3-51.6], $\mathrm{p}<0.001)$, Figure 2c. For SGF significant factors were: non-malignant disease (HR 4.31 [1.06-17.5], $\mathrm{p}=0.04)$, and lymphoma (HR 4.19 [1.71-10.3], p=0.002), Figure 2d. Taken together, non-leukemia diagnosis and mismatched unrelated or haploidentical donors were significantly associated with graft failure (see Figure 2e).

The effect of more than one of the previously described risk factors (non-leukemia diagnosis and mismatched unrelated or haploidentical donors) on the occurrence of graft failure is shown in Figure 2e. For the absence of any of the risk factors $(n=279)$, the incidence of GF was 3.6\%. For the presence of one risk factor $(n=229)$, the incidence of GF was $9.9 \%$, while for 2 concurrent risk factors $(n=49)$, the incidence of GF was $24.5 \%$.

\section{Discussion}

GF remains a significant clinical problem post allo-HCT. It is important to identify patients who are at risk of GF to potentially limit the number of risk factors for prevention of this high-risk complication. Our study showed an increased risk for GF following the use of mismatched unrelated or haploidentical donors for diseases such as lymphoma, myelofibrosis, myelodysplastic syndrome and non-malignant diseases.
A number of factors found significant in other studies were not significant on multivariate analysis in the present study. Cryopreservation was a significant factor in a large retrospective study on PGF from CIBMTR data, but this was not significant in the present cohort $(p=0.79)$ [6]. This may be due to the more rigorous standardization of cryopreservation and thawing techniques at our center, compared to the multicenter data in the CIBMTR study. Other stated significant factors from the CIBMTR study, including age, bone marrow source, ABO incompatibility and sex-mismatched transplants (male recipients of female grafts) were similarly not significant on multivariate analysis in the present study. This may be related to our limited numbers compared to the 23,272 transplants examined in the CIBMTR study. Both the present study and the CIBMTR study are in concordance that HLA-mismatch and non-leukemic myeloid malignancies are significant risk factors for GF. Possible explanations for the differences in other results include the use of myeloablative conditioning as an inclusion criterion in the CIBMTR study, the use of haploidentical donors at our center, and the exclusive examination of PGF in the CIBMTR study. In support of our findings, another report has similarly identified mismatched donors and non-malignant conditions as significantly associated with GF on multivariate analysis [1]. Other factors also identified in this single-center report which identified GF in 54 (5.6\%) patients of 967 transplants undertaken from 1995 to 2010 , were non-myeloablative conditioning, total nucleated cell dose $<2.4 \times 10^{8} / \mathrm{kg}$, HLA-mismatch and ex vivo T-cell depletion. We analyzed separately effects of CD34 dose above and below the median, as well as stem cell source, but there were no significant associations in all GF or in PGF-only patients.

Treatment strategies for GF vary, while second transplant remains a common option, particularly in our center, as CD34-selected stem cell boost is not available. Using data reported to the National Marrow Donor Program (NMDP) of 14,564 transplants, of which 981 experienced PGF, Schriber, et al. (2010) described 122 patients who received a subsequent second unrelated transplant [21]. One-year OS after the second HCT was $11 \%$, with only 10 patients alive at the last follow-up. The cumulative probability of NRM was high at $39 \%$ and $75 \%$ at 30 and 100 days, respectively. In this study, engraftment data from 79 patients were included, and the cumulative incidence of neutrophil engraftment at 28 days was $66 \%$. Survival was poor $(10 \%)$ for patients who received a second allo-HCT; however, the mortality rate was $99 \%$ at 1 year in patients not undergoing a second HCT. Only 162 patients out of 981 reported with GF had received a second HCT, of which 122 were from unrelated donors. This could be because the first HCT was from an unrelated donor, making the attainment of a second donation more complicated than from a related donor. However, where donors were available for the second SCT, no differences were observed between patients who received grafts from the same $(80 \%)$ or a different donor, or if the stem cells had been previously cryopreserved.

In contrast to our findings and that of the CIBMTR study, the MD Anderson group7 reported 68 patients out of 1726 who experienced GF, showing that a diagnosis of acute leukemia was found to be the only prognostic marker for sur- 
vival on multivariate analysis [7]. A patient was considered to have GF if any of these 3 conditions were met: (1) PGF: failure to achieve ANC of $<0.5 \times 10^{9} / \mathrm{L}$ by 28 days after BM or $\mathrm{PB}$ progenitor cell transplantation or 42 days after cord blood (CB) transplantation, (2) SGF: loss of neutrophil engraftment as determined by an ANC of $<0.5 \times 10^{9} / \mathrm{L}$ for 3 consecutive days after having achieved neutrophil engraftment with documented donor cell chimerism and no evidence of disease progression in the marrow, or (3) PGF with autologous reconstitution defined as achievement of an ANC of at least $0.5 \times 10^{9} / \mathrm{L}$ but without evidence of at least $5 \%$ or more donor cell chimerism as defined by cytogenetics or molecular techniques [7]. They reported a 1-, 2- and 5-year OS of $31 \%, 24 \%$ and $15 \%$, respectively. The most common causes of death were original malignancy (41\%), infection (27\%), and GF (18\%). Twenty-nine patients had PGF, with a median survival of 2.9 months, and 7 were re-transplanted, with only 2 surviving over 5 months. 9 patients had GF with autologous reconstitution, and their median survival was 13.7 months. Thirty patients had SGF; 3 patients survived over 4 years. Five of the 30 received a second transplant, but none survived longer than a year. Overall, patients with autologous reconstitution survived longer, but long-term outcomes were similar.

Using different methodology, a Spanish group reported the outcome of 89 patients with GF, irrespective of donor chimerism [2]. This group used the standard criteria for PGF and SGF was defined as a recurrent ANC $<0.5 \times 10^{9} / \mathrm{L}$ for at least 7 days. They did not state chimerism as a requirement for SGF. Of these, 80 patients received a second allo-HCT, with a 5-year survival probability of $31 \%$ (95\% confidence interval [CI]: 18-44\%), NRM 47\% (95\% CI 36-58\%), and relapse $21 \%$ (95\% CI 4-28\%).

A review of various studies highlights the significant discordance in definitions of SGF: some authors include the presence of donor chimerism in the definition, whilst others do not $[1,2,4,6,7,8,9,10]$. Including those cases with low blood counts which may be secondary to causes such as drugs, infection and GvHD may lead to over-diagnosis and possibly inappropriate treatment, given that a proportion of these will be transient and demonstrate recovery of blood counts. This lack of uniformity may hamper common definitions of what constitutes GF [3]. A definition of SGF which requires donor chimerism $<5 \%$ will exclude patients who had falling chimerism (between $5 \%$ and $95 \%$ ) but insufficient time for this to fall below $5 \%$, or those who died due to cytopenia without documenting $<5 \%$ donor chimerism. We, therefore, included patients with cytopenia, who had falling donor chimerism (Figure 1c) and died due to complications or received salvage DLI or second transplant. Importantly, we excluded those patients whose cytopenia was due to relapse. We were assiduous in ensuring that the presenting cytopenia were not due to relapse of the underlying disease. This serves to reduce ambiguity and focus resources on those patients in urgent need of salvage from GF. Often, relapsed myelodysplasia or acute leukemia may present with progressive single- or multi-lineage cytopenia, and it is crucial to make every attempt to exclude relapse, either by repeated bone marrow examination or the use of modern techniques for minimal or measurable residual disease by flow cyto- metry and/or quantitative polymerase chain reaction, as appropriate.

Interestingly, the significant factors for primary and SGF in our cohort were slightly different, which may represent that these types of GF represent different phenomena, with differing mechanisms. This is evidenced by the fact that PGF risks included myelofibrosis, myelodysplasia, myeloproliferative neoplasm, while these were absent from those factors found significant for SGF (lymphoma/non-malignant diagnosis, Figures $2 \mathrm{c}$ and $2 \mathrm{~d}$ ).

There are limitations to our analysis. Numbers of patients with primary or SGF are few and therefore the analysis was improved by evaluating all GF together. Nevertheless, analysis within primary and SGF cohorts gave broadly similar results. The inclusion of patients who died with cytopenia in the SGF may not be conventional, but this allowed study of relevant groups which would have otherwise have been excluded.

\section{Conclusion}

According to the results from the present study, the prognosis of GF remains poor even after successful treatment of GF, with a few long-term survivors. Those patients with mismatched donors and certain hematological conditions as previously mentioned, should be counselled carefully that the risk of GF may be near $25 \%$, with a mortality rate of approximately 73-89\% should it occur. Whereas risk factors such as primary diagnosis are unavoidable, it may be possible to reduce the other risk factors, including careful donor selection. However, most patients with MMUD or haploidentical donors will not have a readily available alternative donor. Measures that could be taken to reduce risk of GF include choice of haploidentical donor, utilizing a more immunosuppressive conditioning regimen or increasing the immunosuppressive component of the GvHD prophylaxis. If appropriate, a myeloablative regimen is more likely to ensure full donor engraftment. Furthermore, careful attention could be paid to the presence of donor-specific antibodies (DSA) and their titers when using MMURD and haploidentical donors. Post-transplant monitoring modification could be implemented, such as lineage-specific chimerism, which our center has recently introduced, and more frequent monitoring of chimerism, e.g. every 30 days with priority for rapid results. More careful use of myelo-suppressive medication such as valganciclovir and co-trimoxazole in these patients is another suggested strategy, with early adoption of alternative therapies in the event of cytopenias. These special precautions could be taken in those cases with 1 or more risk factors as identified in this study. Further studies are required to establish whether close monitoring and early intervention improve outcomes. The optimal treatment strategies for graft failure remain to be established.

\section{Conflicts of interests}

None declared. 


\section{References}

1. Olsson R, Remberger M, Schaffer M, et al. Graft failure in the modern era of allogeneic hematopoietic SCT. Bone Marrow Transplant. 2013;48(4):537-543.

2. Ferra C, Sanz J, Diaz-Perez MA, et al. Outcome of graft failure after allogeneic stem cell transplant: study of 89 patients. Leuk Lymphoma. 2015;56(3):656-662.

3. Gale RP. Early and late graft-failure after transplants. Bone Marrow Transplant. 2016;51(2):182-183.

4. Satwani P, Jin Z, Duffy D, et al. Transplantation-related mortality, graft failure, and survival after reduced-toxicity conditioning and allogeneic hematopoietic stem cell transplantation in 100 consecutive pediatric recipients. Biol Blood Marrow Transplant. 2013;19(4):552-561.

5. Ozdemir ZN, Civriz Bozdag S. Graft failure after allogeneic hematopoietic stem cell transplantation. Transfus Apher Sci. 2018;57(2):163-167.

6. Olsson RF, Logan BR, Chaudhury S, et al. Primary graft failure after myeloablative allogeneic hematopoietic cell transplantation for hematologic malignancies. Leukemia. 2015;29(8):1754-1762.

7. Rondon G, Saliba RM, Khouri I, et al. Long-term follow-up of patients who experienced graft failure postallogeneic progenitor cell transplantation. Results of a single institution analysis. Biol Blood Marrow Transplant. 2008;14(8):859-866.

8. Passweg JR, Zhang MJ, Rocha V, et al. Donor characteristics affecting graft failure, graft-versus-host disease, and survival after unrelated donor transplantation with reduced-intensity conditioning for hematologic malignancies. Biol Blood Marrow Transplant. 2011;17(12):1869-1873.

9. Hutt D. Engraftment, Graft Failure, and Rejection. In: Kenyon M, Babic A, eds. The European Blood and Marrow Transplantation Textbook for Nurses: Under the Auspices of EBMT. Cham (CH)2018:259-270.

10. Lund TC, Liegel J, Bejanyan N, et al. Second allogeneic hematopoietic cell transplantation for graft failure: poor outcomes for neutropenic graft failure. Am J Hematol. 2015;90(10):892-896.

11. Mattsson J, Ringden O, Storb R. Graft failure after allogeneic hematopoietic cell transplantation. Biol Blood Marrow Transplant. 2008;14(1 Suppl 1):165-170.

12. Masouridi-Levrat S, Simonetta F, Chalandon Y. Immunological Basis of Bone Marrow Failure after Allogeneic Hematopoietic Stem Cell Transplantation. Frontiers in immunology. 2016;7:362.

13. Wolff SN. Second hematopoietic stem cell transplantation for the treatment of graft failure, graft rejection or relapse after allogeneic transplantation. Bone Marrow Transplant. 2002;29(7):545-552.

14. Stucki A, Leisenring W, Sandmaier BM, Sanders J, Anasetti C, Storb R. Decreased Rejection and Improved Sur- vival of First and Second Marrow Transplants for Severe Aplastic Anemia (A 26-Year Retrospective Analysis). Blood. 1998;92(8):2742-2749.

15. Przepiorka D, Weisdorf D, Martin P, et al. 1994 Consensus Conference on Acute GVHD Grading. Bone Marrow Transplant. 1995;15(6):825-828.

16. Jagasia MH, Greinix HT, Arora M, et al. National Institutes of Health Consensus Development Project on Criteria for Clinical Trials in Chronic Graft-versus-Host Disease: I. The 2014 Diagnosis and Staging Working Group report. Biol Blood Marrow Transplant. 2015;21(3):389-401 e381.

17. Ferrà C, Sanz J, Díaz-Pérez M-A, et al. Outcome of graft failure after allogeneic stem cell transplant: study of 89 patients. Leukemia \& Lymphoma. 2015;56(3):656-662.

18. Fine JP, Gray RJ. A Proportional Hazards Model for the Subdistribution of a Competing Risk. Journal of the American Statistical Association. 1999;94(446):496-509.

19. Kanda Y. Investigation of the freely available easy-to-use software 'EZR' for medical statistics. Bone Marrow Transplant. 2013;48(3):452-458.

20. Sorror ML, Maris MB, Storb R, et al. Hematopoietic cell transplantation (HCT)-specific co-morbidity index: a new tool for risk assessment before allogeneic HCT. Blood. 2005;106(8):2912-2919.

21. Schriber J, Agovi MA, Ho V, et al. Second unrelated donor hematopoietic cell transplantation for primary graft failure. Biol Blood Marrow Transplant. 2010;16(8):1099-1106.

22. Armand P, Gibson CJ, Cutler C, et al. A disease risk index for patients undergoing allogeneic stem cell transplantation. Blood. 2012;120(4):905-913. 


\title{
Факторы риска недостаточности трансплантата при аллогенной трансплантации гемопоэтических стволовых клеток: одноцентровое исследование
}

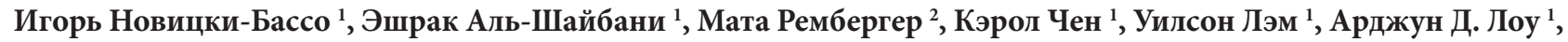 \\ Айвэн Пазич ${ }^{1}$, Фотиос В. Микелис ${ }^{1}$, Ауро Висвабандья ${ }^{1}$, Деннис Д. Ким ${ }^{1}$, Джеффри Х. Липтон ${ }^{1}$, Армин Гербитц ${ }^{1}$, \\ Ионас Маттсон ${ }^{1}$, Раджат Кумар ${ }^{1}$, Зейяд Аль-Шайбани ${ }^{1}$ \\ ${ }^{1}$ Программа аллогенных трансплантаций Ханса Месснера, Онкологический Центр принцессы Маргарет, \\ университетская сеть здравоохранения, Университет Торонто, Торонто, Канада \\ 2 Департамент медицинских наук, университет Уппсала, университетский госпиталь Уппсала, Уппсала, Швеция
}

\section{Резюме}

\section{Цель работы}

Недостаточность трансплантата (НТ) после аллогенной трансплантации гемопоэтических клеток (алло-ТГСК) имеет плохой прогноз. Целью данного исследования было установление частоты возникновения, факторов риска (Фри исходов НТ в контингенте из одного центра.

\section{Пациенты и методы}

В период с 2015 по 2018 гг., алло-ТГСК была выполнена у 557 больных. Первичную НТ (ПНТ) определяли как отсутствие роста абсолютного количества нейтрофилов $\left(\mathrm{AКН)} \mathrm{до}>0.5 \times 10^{9}\right.$ /л к 28 сут. после алло-ТГСК. Вторичную НТ (ВНТ) характеризовало снижение числа донорских клеток после начального приживления с возвратом КН к уровням $<0.5 \times 10^{9} /$ л без рецидива или иных причин цитопении. Конечными результатами исследования была кумулятивная встречаемость НТ и общая выживаемость (OB); факторы риска НТ определяли путем многофакторного анализа.

\section{Результаты}

В 9 случаях выявлена ПНТ, и у 34 больных была ВНТ. Кумулятивная встречаемость НТ была, соответственно, 1,6\% ко дню +100 (СI95\%; 0,8- 3,0\%), и $6,5 \%$ - (CI95\%; 4,5-8,8\%) ко дню +800. Многофакторный анализ показал, что лиагноз (миелодиспластический синдром, миелофиброз, лимфома или неопухолевые заболевания), а также тип донора
(HLA-несовместимый неродственный или гаплоидентичный) были достоверно ассоциированы с НТ. Частота НТ составила 3,6\% при отсутствии указанных факторов риска, 9.9\% при наличии одного ФР и $24.5 \%$ при двух ФР. Медиана выживаемости пациентов после ПНТ составила 41 сут., после ВНТ - 144 сут. Общая выживаемость на день +100 при ПНТ была 22\%, при ВНТ - 64\%. Двухлетняя общая выживаемость в случаях ВНТ была $28 \%$.

\section{Выводы}

Данное исследование показало наличие повышенного риска недостаточности трансплантата после алло-ТГСК от несовместимого/неродственного или гаплоидентичного донора, или при нелейкемическом диагнозе. Для таких случаев мы предлагаем тщательный мониторинг, ранние диагностические и терапевтические мероприятия и для улучшения клинических исходов.

\section{Ключевые слова}

Аллогенная трансплантация гемопоэтических стволовых клеток, недостаточность трансплантата, встречаемость, факторы риска. 